\title{
EFEK PEMAPARAN TEGANGAN LISTRIK SEARAH TERHADAP PERTUMBUHAN TANAMAN SAWI (BRASSICA JUNCEA L) MENGGUNAKAN METODE ELEKTROOSMOSIS TIPE ELEKTRODA VERTIKAL
}

\section{Effect of DC Voltage Exposure to the Growth of Brassica Juncea L by Electroosmosis Method and Vertical Electrode Type}

\author{
Joko Prasetyo*, Bayu Permadi, Anang Lastriyanto \\ Jurusan Keteknikan Pertanian - Fakultas Teknologi Pertanian -Universitas Brawijaya \\ Jl. Veteran - Malang 65145 \\ Penulis Korespondensi, email : joko.prasetyo@ub.ac.id
}

Disubmit: 30 Juli 2019 Direvisi: 19 Nopember 2019 Diterima: 25 Nopember 2019

\begin{abstract}
ABSTRAK
Secara umum penelitian ini bertujuan untuk mengetahui pengaruh adanya beda potenisial listrik dengan berbagai tegangan input di dalam tanah dan lama waktu pemaparan terhadap petumbuhan dari tanaman sawi dengan parameter berupa tinggi tanaman, jumlah daun, kehijauan daun, panjang dan lebar stomata serta berat basah tanaman sawi. Penelitian ini menggunakan 3 kali pengulangan dan 2 faktor, dengan faktor pertama besar tegangan listrik elektroosmosis $(1,5 \mathrm{~V}, 3 \mathrm{~V}$ dan 4,5V) dan faktor kedua lama pemaparan tegangan listrik elektroosmosis (1 jam, 2 jam dan 3 jam). Faktor lingkungan yang meliputi suhu udara, kelembaban udara dan cahaya dikondisikan seragam untuk semua perlakuan. Pemberian pupuk dan penyiraman untuk semua sampel diperlakukan sama. Berdasarkan penelitian dapat diketahui bahwa pemaparan tegangan elektroosmosis dapat mempengaruhi pertumbuhan dari tanaman sawi. Hasil yang didapat juga menyimpulkan bahwa perlakuan tegangan 3 Volt merupakan perlakuan yang terbaik dengan memberikan perbedaan yang nyata. Waktu yang terbaik untuk pemaparan tegangan yaitu selama satu jam untuk parameter jumlah daun, kehijauan daun, panjang dan lebar stomata serta berat basah. Sedangkan untuk parameter tinggi tanaman yaitu selama dua jam

Kata kunci: Elektroosmosis; Pertumbuhan; Sawi; Tegangan DC

\section{ABSTRACT}

In general, this study aimed to determine the effect of electric potential differences with various input voltages in the soil and the length of exposure to mustard plants growth with parameters such as plant height, leaf number, leaf greenery, stomata length and width, and wet weight of mustard plants. This study uses 3 repetitions and 2 factors, with the first factor was electro-osmosis electrical voltage $(1.5 \mathrm{~V}, 3 \mathrm{~V}$, and $4.5 \mathrm{~V})$ and the second factor was the length of electro-osmosis electrical voltage exposure (1 hour, 2 hours, and 3 hours). Environmental factors which include air temperature, humidity and light are uniformly conditioned for all treatments. there was no difference in treatment for water and fertilizer for all plant samples. Based on the research, it can be seen that electro-osmosis voltage exposure can affect the growth of mustard plants. The results obtained also concluded that the 3 Volt voltage is the best treatment by giving a real difference. The best time for stress exposure is one hour for parameters of number of leaves, greenness of leaves, length and width of stomata and wet weight, while for parameters of plant height that is for two hours
\end{abstract}

Keywords : DC Voltage; Electro-osmosis; Brassica Juncea L; Growth 


\section{PENDAHULUAN}

Tanaman sawi merupakan salah satu dari tanaman hortikultura yang dibutuhkan oleh manusia untuk memenuhi kebutuahan vitamin dan mineral yang berfungsi sebagai pemenuhuan gizi masyarakat. Selain itu, tanaman sawi juga memiliki prospek baik untuk mendukung upaya peningkatan pendapatan petani, perluasan kesempatan kerja, pengembangan agribisnis, peningkatan pendapatan negara melalui pengurangan impor dan memacu laju pertumbuhan ekspor. Produksi sawi di Indonesia meningkat dari tahun 2008 hingga tahun 2012 yaitu 565.636 ton, 562.838 ton, 583.770 ton, 580.969 ton, 594.911 ton per hektar, namun dapat dilihat dari produktivitas tanaman sawi yang mengalami penurunan yaitu 103,6 ton, 99,8 ton, 98,2 ton, 94,4 ton, dan 97,4 ton per hektar (Departemen Pertanian, 2012). Keberlanjutan subsektor sayuran sebenarnya melekat dalam hubungan antara manusia dengan iklim, terutama berkaitan dengan bagaimana manusia menyikapi perubahan iklim dan seberapa besar dampak perubahan iklim terhadap agroekosistem sayuran (Adiyoga dan Basuki, 2018). Kemarau panjang merupakan salah satu contoh dampak perubahan iklim yang menimbulkan konsekuensi menurunnya tingkat produksi dari sayur-sayuran terutama tanaman sawi yang akan berdampak langsung pada malnutrisi akut bagi masyarakat. Curah hujan merupakan unsur iklim yang besar pengaruhnya terhadap budidaya tanaman di daerah tropis terutama pada lahan kering dan tadah hujan (Norma dan Jauhari, 2008). Dalam hal ini curah hujan menentukan pola dan intensitas tanaman yang dicirikan oleh musim tanam (growing season) suatu lahan. Berbeda dengan daerah sub-tropis dan temperate, di Indonesia curah hujan merupakan satu-satunya penentu musim tanam, karena hampir semua tipe agroekosistem yang ada dapat ditanami sepanjang tahun dengan syarat kebutuhan air tercukupi dengan baik. Di wilayah lahan non teknis/kering dataran tinggi petani hanya mampu menanam komoditas hortikultura pada musim hujan dan pada musim kemarau menanam komoditas yang toleran kekeringan. Tekologi sederhana yang sudah ada untuk mengatasi masalah di lahan non teknis/kering adalah dengan irigasi tetes. Namun, sistem irigasi tersebut belum dapat dimanfaatkan secara optimal dikarenakan irigasi tetes memerlukan perawatan yang intensif karena resiko penyumbatan akibat penumpukan garam sangat tinggi. Ditambah lagi penerapan irigasi tetes dapat membatasi pertumbuhan tanaman dan memerlukan biaya yang tinggi untuk pembangunan, pengoprasian serta perawatannya (Apriani $e t$ al, 2015). Oleh karena itu, diperlukan teknologi tepat guna, murah dan aplicable untuk mengatur ketersediaan air agar dapatmemenuhi kebutuhan air (water demand) yang semakin sulit dilakukan dengan caracara alamiah (natural manner). Elektroosmosis adalah teknologi yang memanfaatkan beda potensial sehingga dapat mengalirkan fluida pada celah kapiler. Teknologi ini dilakukan dengan cara menempatkan katoda dan anoda didalam tanah dengan suatu jarak tertentu. Medan listrik dengan arus listrik searah diiberikan diantara katoda dan anoda sehingga air akan mengalir dari anoda ke katoda (Wicaksono, 2012). Elektroosmosis merupakan salah satu metode untuk mengatur ketersediaan air dengan memanfaatkan arus listrik satu arah (DC) secara langsung. Arus listrik ini akan mengikat air dan membawanya bergerak mengikuti arah aliran listrik tersebut. Jika dua elektroda dipasang pada tanah yang lembab dan dialirkan listrik, maka air yang terkandung di dalam tanah akan bergerak dari elektroda positif menuju elektroda negatif (Andi et al, 2013). Adanya potensi elektroosmosis dalam menarik air merupakan hal yang melatar belakangi penelitian ini. Penelitian ini akan berfokus pada pengaruh adanya beda potenisial listrik dengan berbagai tegangan input di dalam tanah dan lama waktu pemaparan terhadap petumbuhan dari tanaman sawi

\section{METODE}

Bahan yang digunakan antara lain bibit sawi, tanah gembur, air, pupuk NPK dan pupuk organik. Sedangkan alat yang digunakan dalam penelitian antara lain penggaris, timbangan digital, kabel, papan tembaga (PCB), power supply, multimeter, stop contact, nampan, polybag, timba, dan gelas ukur. 


\section{Metode}

\section{A. Perlakuan Pada Tanaman}

a) Persemaian

Sebelum ditanam pada polybag, dilakukan penyemaian benih selama 3 minggu dan tanaman telah memiliki daun 3- 4 helai (Tambunan et al, 2013). Media tanam yang digunakan adalah tanah yang telah dicampur dengan pupuk organik.

\section{b) Penanaman}

Bibit umur 3 minggu setelah semai atau telah berdaun 3-4 helai, dipindahkan pada lubang tanam yang telah disediakan dalam polybag. Polybag yang digunakan berdiameter $15 \mathrm{~cm}$. Berat media tanam sebesar $3 \mathrm{Kg}$ (Tambunan et al, 2013). Media tanam yang digunakan berupa tanah halus, pupuk kandang/kompos dan arang sekam dengan perbandigan 1:1:1 (Mailina et al, 2016).

\section{c) Pemupukan}

Pemupukan pertama yaitu dengan memberikan pupuk organik pada media tanam yang telah dicampur dengan tanah dengan dosis 1:1. Pemupukan susulan dilakukan pada umur 10 dan 20 hari setelah tanam dengan memberikan pupuk NPK (1:1:1) cair sebanyak $2 \mathrm{gr} / 200 \mathrm{ml} /$ tanaman dengan cara sistem kocor/siram (Mailina et al, 2016). d) Pemeliharaan

Penyiraman dilakukan setiap hari yaitu pagi pada pukul 07.00 WIB secara merata pada seluruh tanaman disesuaikan dengan kondisi lapangan. Penyiraman dilakukan sebanyak 300ml/tanaman. Penyiangan dilakukan secara manual yaitu dengan mencabut gulma yang tumbuh (Mailina et al, 2016).

\section{e) Panen}

Pemanenan dilakukan pada saat tanaman berumur 32 hari setelah tanam. Tanaman sawi dicabut hingga akar untuk dilakukan pengamatan.

\section{B. Rancangan Sistem Elektroosmosis}

Pemberian tegangan listrik dilakukan setiap hari selama 32 hari. Tegangan listrik diberikan setelah dilakukan penyiraman. Elektroda yang digunakan berupa papan PCB yang dilapisi tembaga dengan ukuran $10 \times 10 \mathrm{~cm}$. Papan PCB ditancapkan diantara tanaman sawi dengan jarak antar elektroda sejauh $10 \mathrm{~cm}$ dan kedalaman $5 \mathrm{~cm}$ dibawah permukaan tanah. Posisi elektroda dapat dilihat pada Gambar 1.

Pemberian tegangan listrik dilakukan dengan tiga variasi tegangan $(1,5 \mathrm{~V}, 3 \mathrm{~V}$ dan $4,5 \mathrm{~V})$ dan tiga variasi waktu (1 jam, 2 jam dan 3 jam) yang dimulai pada pukul 7 hingga pukul 10 pagi, dengan tiga kali pengulangan. Pada pengulangan pertama elektroda dialiri tegangan listrik yang bersumber dari adaptor langsung, sedangkan pengulangan kedua dan ketiga dihubungkan menggunakan kabel jumper. Skema rangkaian dapat dilihat pada Gambar 2 dan Gambar 3.

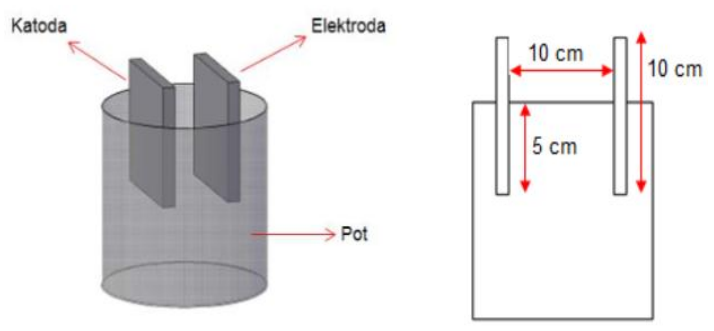

Gambar 1. Sketsa elektroda

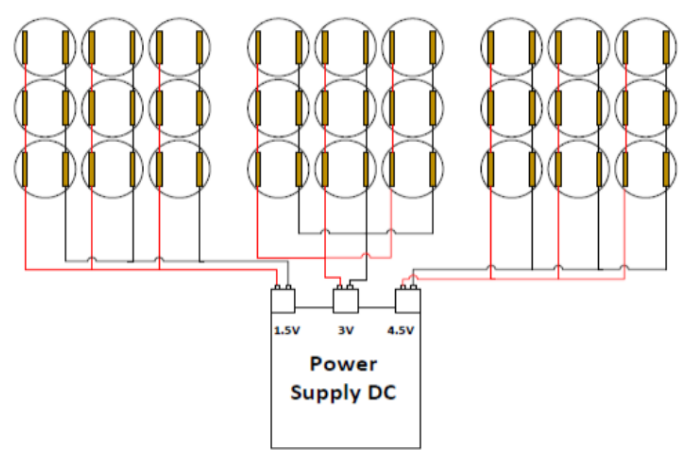

Gambar 2. Skema rangkaian

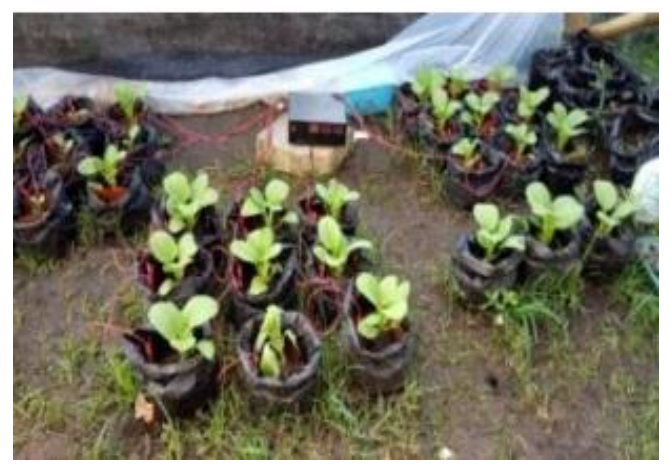

Gambar 3. Perlakuan pada tanaman

C. Metode Pengukuran

a) Tinggi Tanaman

Pengukuran tinggi tanaman $(\mathrm{cm})$ dimulai dari permukaan tanah (pangkal batang) sampai ujung daun tertinggi dari tanaman (Oktabriana, 2017). Pengukuran tinggi tanaman menggunakan penggaris.. Pengukuran tinggi tanaman dilakukan empat hari sekali yaitu pada hari ke-0. 4, 8, 12, 16, 20, 24,28 , dan 32 , setelah pindah tanam. 


\section{b) Jumlah Daun}

Penghitungan jumlah daun dihitung berapa banyak daun tanaman sawi yang telah membuka pada saat pengamatan (Oktabriana, 2017). Pengukuran jumlah daun dilakukan empat hari sekali yaitu pada hari ke- $0,4,8,12$, 16, 20, 24, 28, 32 setelah pindah tanam.

c) Pengukuran Kadar Klorofil

Penentuan kehijauan daun menggunakan alat klorofilmeter. Sampel daun sawi diukur dengan tiga kali pengukuran untuk mendapatkan satu nilai klorofil meter total. Daun yang akan diukur kadar klorofilnya dijepitkan pada bagian sensor dari klorofilmeter. Sensor ditempatkan di bagian pangkal, tengah, dan ujung daun secara acak hanya pada bagian mesofil daun dengan menghindari bagian tulang daun (Robbani, 2015).

d) Pengamatan dan Pengukuran Stomata

Penentuan panjang dan lebar pori stomata dilakukan dengan dua tahap: tahap pertama pengamatan menggunakan mikroskop dengan metode replikasi dan tahap kedua pengukuran panjang serta lebar stomata. Prosedur pembutan preparat menurut Taluta et al, (2017) adalah sebagai berikut: langkah pertama adalah membuat irisan memanjang epidermis daun bagian bawah. Kedua, hasil irisan epidermis diletakan di atas gelas benda. Ketiga, ditutup dengan gelas penutup, agar tidak tidak lepas sudut-sudut gelas penutup ditetesi cat kuku dan diberi label. Selanjutnya mikroskop dihubungkan dengan optilab menggunakan program Image Raster tipe 3.

e) Berat Basah

Penimbangan berat basah tanaman dilakukan pada semua tanaman uji dengan menggunakan timbangan digital. Penimbangan dilakukan secara terpisah bagian atas tanaman (batang dan daun) dan bagian bawah tanaman (akar). Sebelum ditimbang tanaman dibersihkan dengan air dan dikeringkan. Penimbangan dilakukan saat tanaman sudah dipanen, yaitu 32 hari setelah tanam.

\section{HASIL DAN PEMBAHASAN}

\section{Tinggi Tanaman Sawi}

Hasil dari Pengamatan tinggi tanaman sawi yang dilakukan selama 32 hari. dapat dilihat pada Gambar 4. Dari hasil pengukuran kecepatan pertumbuhan dari berbagai perlakuan menunjukan hasil yang relativ sama.
Kecepatan pertumbuhan dari perlakuan tegangan $3 \mathrm{~V}$ memiliki kecepaan pertumbuhan yang lebih baik dari pada perlakuan tegangan $1,5 \mathrm{~V}$ dan $4,5 \mathrm{~V}$ yaitu dengan rata-rata kecepatan petumbuhan 0,61 $\mathrm{cm} /$ hari. Menurut Yi et al (2012) pada penelitiannya menjelaskan bahwa kecepatan pertumbuhan selada dan lama pertumbuhan tanaman cabai telah diaktifkan atau ditingkatkan dengan adanya electric pulse. Menurut Castaneda et al (2016), pemberian arus listrik dan tegangan listrik tertentu dapat mempercepat pertumbuhan dari tanaman selada pada sistem hidroponik.

Hasil Penelitian juga memperlihatkan kecepatan rata-rata pertumbuhan dari berbagai perlakuan pemberian tegagan $(1,5 \mathrm{~V}$, $3 \mathrm{~V}$ dan $4,5 \mathrm{~V}$ ) dengan lama waktu pemaparan. Dari grafik tersebut dapat dilihat bahwa kecepatan rata-rata pertumbuhan yang terbaik adalah pada pemaparan tegangan listrik selama 2 jam/hari yaitu dengan kecepatan pertumbuhan sebesar 0,63 $\mathrm{cm} /$ hari. Penelitian dari Novak dan Bjelis (2015) menjelaskan bahwa pemberian tegangan listrik berdampak positif terhadap kecepatan perkecambahan dan pertumbuhan tanaman buncis.

\section{Jumlah Daun}

Adapun hasil dari pengamatan pertambahan jumlah daun selama 32 hari ditunjukan pada Gambar 5. Dari hasil pengukuran pertambahan jumlah daun dari berbagai perlakuan menunjukan hasil yang relativ sama, namun pemberian tegangan memiliki pertambahan yang lebih besar dibanding dengan tanpa pemberian tegangan. Pemberian tegangan 3V memiliki nilai rata-rata pertambahan jumlah daun yang lebih baik dibanding perlakuan lainnya yaitu sebesar 0,4 helai/hari. Menurut Shenker et al (2005), Pelarutan fosfat dapat diaktifkan oleh pulsa listrik karena reaksi redoks dan variasi $\mathrm{pH}$ adalah proses utama yang mengarah pada pelepasan fosfor di tanah. Sedangkan Pertambahan jumlah daun dipengaruhi oleh kandugan unsur hara berupa fosfor di dalam tanah. Fosfat dibutuhkan oleh tanaman untuk pembentukan sel pada jaringan dan tunas yang sedang tumbuh (Liferdi, 2010). Hal tersebut yang menyebabkan pertambahan jumlah daun pada perlakuan pemberian tegangan lebih besar. 


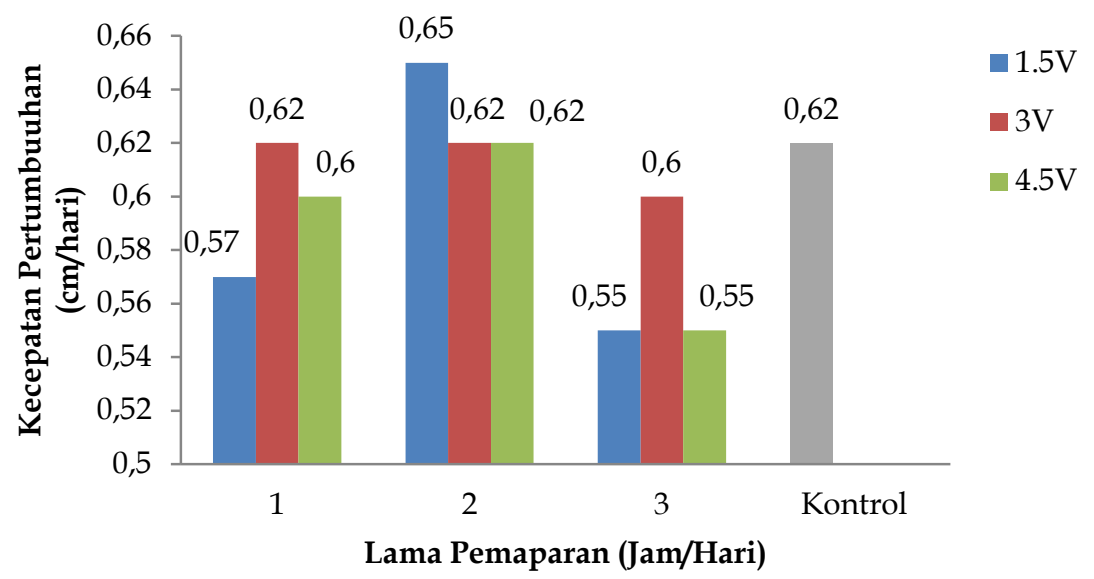

Gambar 4. Grafik kecepatan pertumbuhan

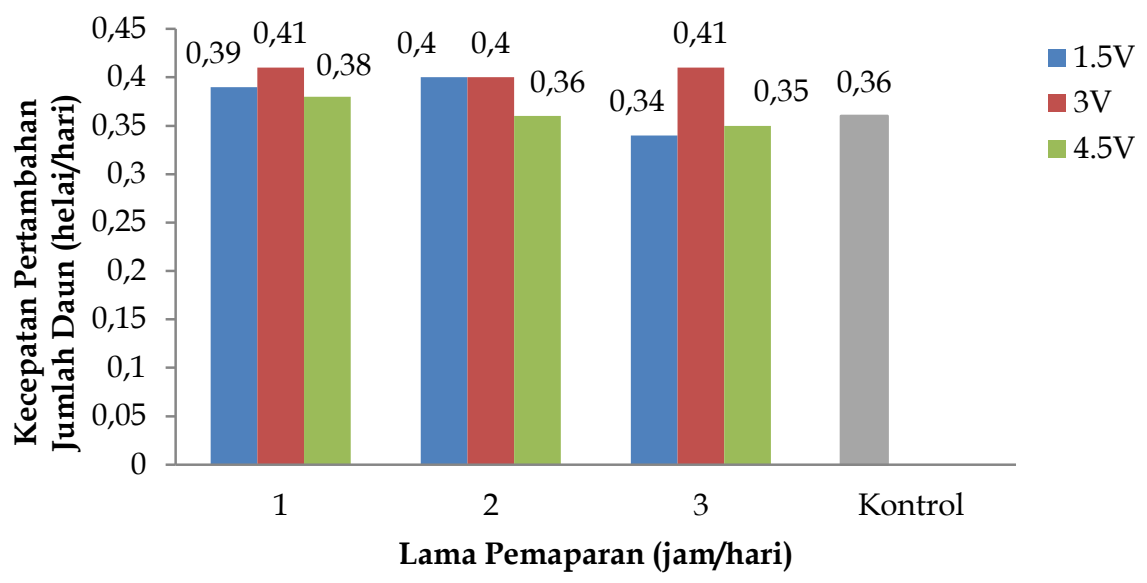

Gambar 5. Grafik pertambahan jumlah daun

\section{Kandungan Klorofil}

Hasil dari pengukuran kandungan klorofil dapat dilihat pada Gambar 6. Dari hasil pengukuran kandungan klorofil dapat disimpulkan bahwa pemberian tegangan listrik tertentu dapat meningkatkan kandungan klorofil daun. Dari hasil yang didapatkan juga dapat disimpulkan bahwa pemberian tegangan $3 \mathrm{~V}$ memiliki nilai rata-rata kandungan klorofil yang lebih besar dibanding dengan $1,5 \mathrm{~V}$ dan $4,5 \mathrm{~V}$, dimana pada tegangan $3 \mathrm{~V}$ memiliki nilai rata-rata sebesar 36,03 sedangkan $1.5 \mathrm{~V}$ dan $4.5 \mathrm{~V}$ berturut-turut sebesar 35,27 dan 35,95. Lama waktu pemaparan juga dapat disimpulkan bahwa pemaparan selama satu jam memiliki nilai yang lebih baik dibanding dengan pemaran dua atau tiga jam. Pemberian electric pulse dengan intensitas rendah dapat meningkatkan kondisi lingkungan dari media tanam (Yi et al 2012). Kehijauan daun dari suatu tanaman dapat meningkatkan kesuburan dari tanaman dikarenakan zat hijau daun digunakan untuk proses fotosintesis (Harjanti et al, 2014).

\section{Panjang dan Lebar Stomata}

Penentuan panjang dan lebar stomata dilakukan menggunakan mikroskop dengan perbesaran 400 kali. Hasil dari pengukuran panjang dan lebar stomata dapat dilihat pada Gambar 7 dan Gambar 8.

Dari grafik tersebut dapat disimpulkan bahwa pemberian tegangan listrik dapat memperpanjang dan memperlebar bukaan dari stomata. Dengan bertambahnya panjang dan lebar stomata maka akan berpengaruh baik terhadap proses fotosintesis. Bukaan pori stomata dengan panjang dan lebar yang besar dapat menghasilkan produksi yang tinggi. Hal ini sesuai dengan penelitian yang 
dilakukan oleh Yudiwanti (2006) yaitu stomata yang membuka lebar nyata berkorelasi dengan bobot polong isi dan bobot biji yang semakin tinggi. Dari hasil tersebut juga dapat disimpulkan bahwa tegangan 3V memiliki nilai rata-rata panjang dan lebar bukaan stomata yang lebih besar dibanding dengan perlakuan tegangan yang lain yaitu sebesar 299,51 $\mu \mathrm{m}$ untuk panjang dan 151,33 $\mu \mathrm{m}$ untuk lebar. Sedangkan untuk lama waktu pemaparan terbaik yaitu selama satu jam.

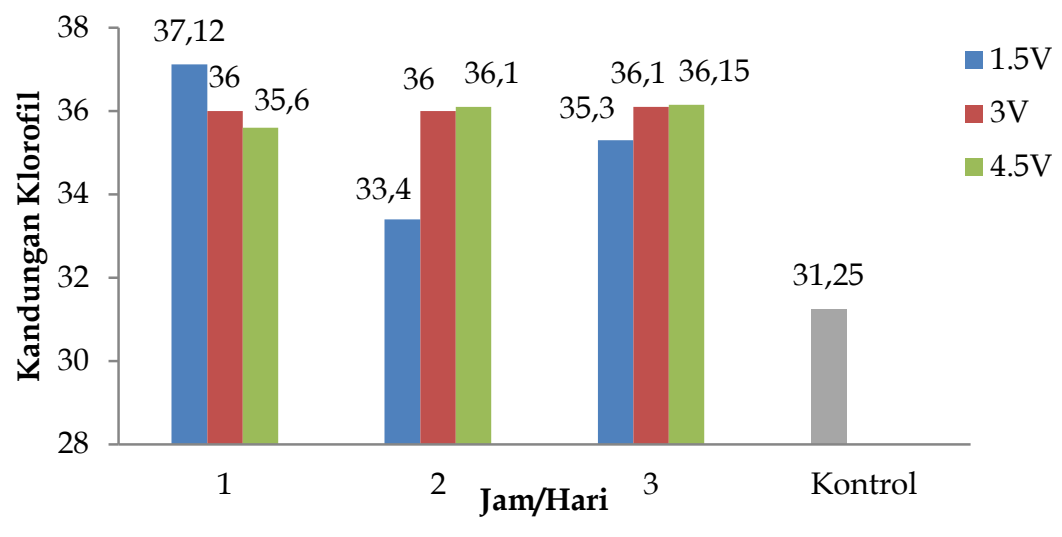

Gambar 6. Grafik kandungan klorofil

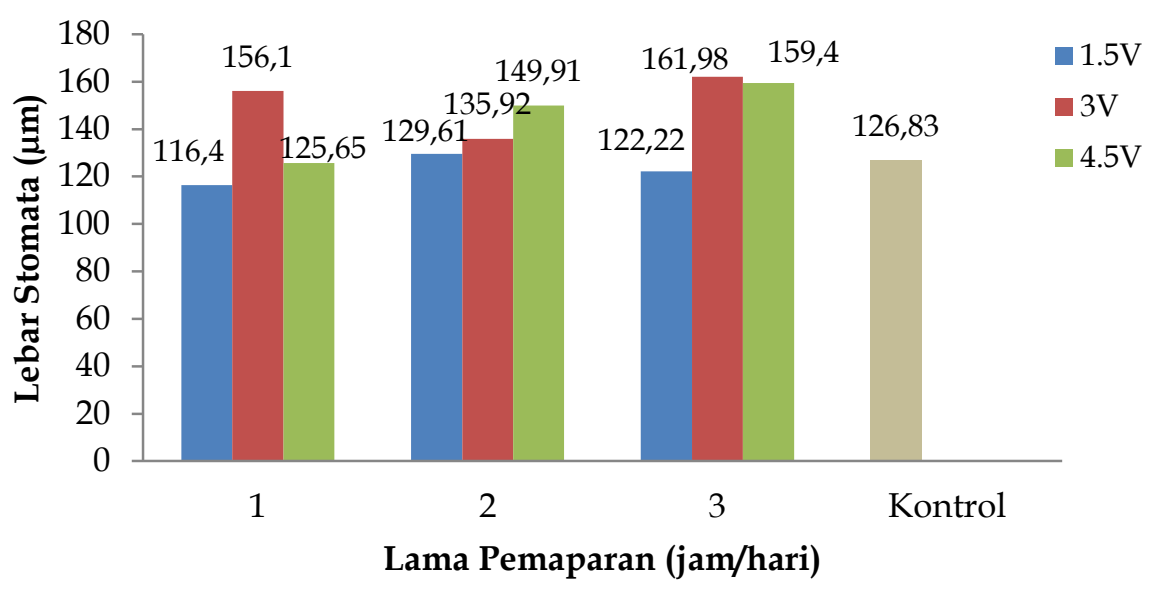

Gambar 7. Grafik Pengukuran Panjang Stomata

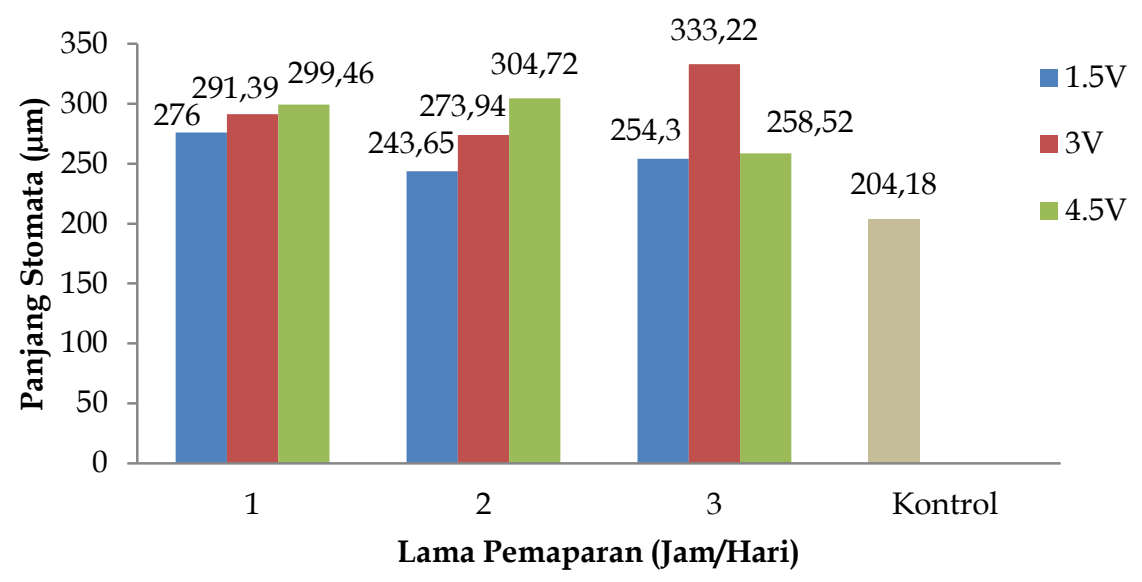

Gambar 8. Grafik pengukuran lebar stomata 


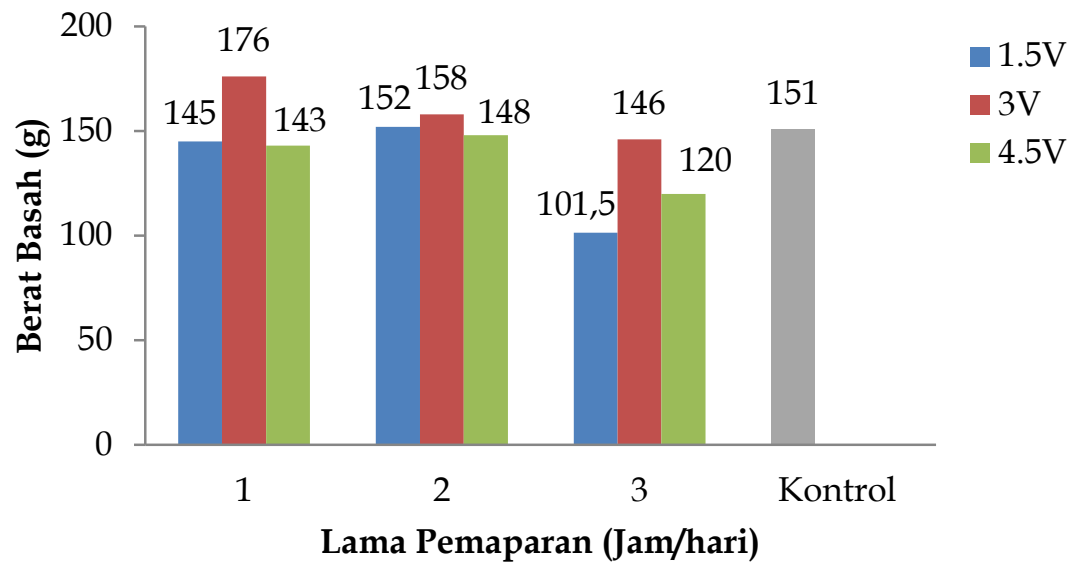

Gambar 9. Grafik pengukuran berat basah

\section{Berat Basah}

Hasil dari pengukuran berat basah tanaman sawi dapat dilihat pada Gambar 9. Dari grafik pengukuran berat basah dapat disimpulkan bahwa berat basah dari perlakuan tegangan memiliki nilai yang relative sama dengan berat basah tanpa perlakuan tegangan. Dari hasil tersebut juga dapat disimpulkan bahwa tegangan $3 \mathrm{~V}$ memiliki nilai rata-rata berat basah yang lebih tinggi dibanding dengan tegangan yang lainnya. Tegangan 3V memiliki rata-rata berat basah sebesar 160 gr sedangkan tegangan $1,5 \mathrm{~V}$ dan $4,5 \mathrm{~V}$ memiliki rata-rata berat basah beturut-turut sebesar 132,8 gr dan 137 gr. Lama pemaparan yang terbaik untuk pemberian tegangan adalah selama satu jam. Pemberian electric pulse dengan intensitas rendah dapat meningkatkan kondisi lingkungan dari media tanam (Yi et al, 2012). Tanah basah yang dibeikan electric pulse dapat menjadi suatu energy untuk mendorong perubahan kondisi lingkungan dengan memindahkan muatan listrik melalui partikel tanah (Nishimura et al, 2009). Dengan meningkatnya kondisi lingkungan maka kondisi media tanam juga akan memiliki kondisi yang baik pula.

\section{SIMPULAN}

Tegangan elektroosmosis memberikan pengaruh terhadap pertumbuhan tanaman sawi yaitu pada pertumbuhan tinggi, jumlah daun, dan berat basah, serta sangat berpengaruh terhadap kehijauan daun, panjang dan lebar stomata daun. Perlakuan lama waktu pemaparan tidak memiliki perbedan yang nyata terhadap parameter pengamatan, namun perlakuan tegangan memiliki pengaruh yang sangat nyata terhadap pertumbuhan tinggi tanaman, jumlah daun, panjang dan lebar stomata serta berat basah tanaman sawi. Perlakuan pemberian tegangan yang terbaik adalah perlakuan V2 atau tegangan 3 volt. Waktu yang terbaik untuk pemaparan tegangan yaitu selama satu jam untuk parameter jumlah daun, kehijauan daun, panjang dan lebar stomata serta berat basah. Sedangkan untuk parameter tinggi tanaman yaitu selama dua jam.

\section{DAFTAR PUSTAKA}

Adiyoga, -W dan R.S. Basuki. 2018. Persepsi petani sayuran tentang dampak perubahan iklim di sulawesi selatan. Balai Penelitian Tanaman Sayuran.

Andi, -T., S. Niken, S, dan D. Noegroho. 2013. Penggunaan metode elektroosmosis pada tanah lempung yang ditambah abu ampas tebu ditinjau dari parameter kuat geser tanah. E-Jurnal Matriks Teknik Sipil. 1(4), 433-439. https://eprints.uns.ac.id/id/eprint/1 1526

Apriani, -H.D., Sumono dan S. Panggabean. 2015. Kajian kinerja irigasi tetes pada tanah latosol dengan budidaya tanaman caisim (Brassica juncea L.). Jurnal Rekayasa Pangan dan Pertanian. 3(1), 109-116. https://jurnal.usu.ac.id/index.php/jrp $\mathrm{p} /$ article/download/9898/pdf

Castaneda, -O.F., M.L.D. Patino., J.D. Patino., R.M.M. Alema, dan O.G.V. Torres. 2016. Effect of electric field on the kinetics of 
growth of lettuce (lactuca sativa) in a hydroponic system. Journal of Agricultural Chemistry and Environment. 5, 113-120. https://doi.org/10.4236/ jacen.2016.53013

Departemen Pertanian. 2012. Produksi Tanaman Sayuran. Jakarta

Harjanti, -R. A., Tohari dan -S. N. H. Utami. 2014. Pengaruh takaran pupuk nitrogen dan silika terhadap pertumbuhan awal (Saccharum officinarumm L.) pada inceptisol. Vegetalika. 3(2), 35-44. https://jurnal.ugm.ac.id/jbp/article/vie $\mathrm{w} / 5150$

Liferdi, -L. 2010. Efek pemberian fosfor terhadap pertumbuhan dan status hara pada bibit manggis. J. Hort. 20(1), 18-26. http:/ / hortikultura.litbang.pertanian.go.i d/jurnal_pdf/201/liferdi_efek_fosfor.pdf

Mailina, -B., E. Novrianty., Gohan, dan D. Rohayana. 2016. Budidaya Sawi Dalam Polybag. Balai Pengkajian Teknologi Pertanian Lampung

Nishimura, -Y., N. Ohta., M. Yamamoto dan I. Yamazaki. 2009. Electric field effect on charger migration of methylene-linked carbazole dan terephthalic acid metyl ester pada PMMA Polymer Film. Jurnal Molekul Kristal dan Liquid Kristal. 181-186. https://doi.org/10.1080/105872598080443 29

Norma, -M.S dan S. Jauhari. 2008. Penerapan irigasi mikro, tumpangsari dan mulsa untuk mengantisipasi kehilangan hasil cabai merah pada penanaman di musim kemarau. Balai Pengkajian Teknologi Pertanian (BPTP) Jawa Tengah

Novak, -V dan Bjelis. 2015. Effect of electricity on growth and development of several plant species. Universty of Croatia

Oktabriana, -G. 2017. Upaya dalam meningkatkan pertumbuhan tanaman sawi hijau (Brassica juncea L.) dengan pemberian pupuk organik cair. Jurnal Agrifo. 2(1), 1-7. https://doi.org/10.29103 /ag.v2i1.310
Robbani, -M.S. 2015. Rancang bangun perhitugan jumlah klorofil pada daun kedelai menggunakan metode fuzzy Mamdani. Skripsi : Jurusan Teknik Informatika Uiversitas Islam Negeri Maulana Malik Ibrahim Malang

Shenker, -M., Seitelbach, -S., Brand, -S., Haim, A. and Li-taor, M.I. 2005. Redox reactions and phosphorus release in reflooded soils of an altered wetland. European Jour-nal of Soil Science. 56, 515525. https://doi.org/10.1111/ j.13652389.2004.00692.x

Taluta, -H.E., H.L. Rampe, dan M.J. Rumondor. 2017. Pengukuran panjang dan lebar pori stomata daun beberapa varietas tanaman kacang tanah (Arachis Hypogea L.). Jurnal MIPA Unsrat. 6(2), 15. https://doi.org/10.35799/jm.6.2.2017 .16835

Tambunan, -M.A., A.Barus, dan J. Ginting. 2013. Respons pertumbuhan dan poduksi sawi (Brassica juncea l) terhadap interval penyiraman dan konsentrasi larutan pupuk npk secara hidroponik. Jurnal Online Agroekoteknologi. 1(3), 864872. https:// jurnal.usu.ac.id/index. php/agroekoteknologi/article/view/3 $181 / 1545$

Wicaksono, -M.A. 2012. Perancangan sistem elektro-osmosis untuk pengendalian air pada batuan candi. Skripsi. Fakultas Matematika dan Ilmu Pengetahuan Alam Institut Teknologi Sepuluh Nopember. Surabaya

Yi, -J. Y., J. W. Choi., -B. Y. Jeon. -I. L. Jung D. H. Park. 2012. Effect of low voltage electric pulse charged to culture soil on plant growth and variation of the bacterial community. Agriculture Science 3(3), 339-346. https://doi.org/10.4236/ as. 2012.37115

Yudiwanti. 2006. Pengaruh Antagonis Stomata Terhadap Ketahanan Pada Penyakit Bercak Daun dan Daya Hasil Pada Kacang Tanah. Prossiding FAPERTA IPB Bogor 